\title{
The Relevance of Peace to Economic Development and Nation Building
}

\author{
Cynado C.N.O. Ezeogidi \\ Division Of General Studies Anambra State University, Uli
}

\begin{abstract}
Post colonial Nigeria has witnessed a lot of conflicts. Some of the conflicts have been very protracted and devastatious. They have also come in different diemensions and colorations. Some of the conflicts are viewed as political conflicts. Others are seen as religious and communal conflicts. The persistent conflicts in different parts of Nigeria is an indication that Nigerians are either not informed of the danger of conflicts or are not trained on the relevance of peace in nation building. The work on relevance of peace in nation building is therefore necessary and timely. This work is therefore an effort to educate our readers on the impact of peace on economic development for nation building. The work shall adopt normative theoretical frame work in its interpretation of absence of peace. It shall rely on oral interview and secondary sources.
\end{abstract}

\section{Introduction}

Peace is so imperative in any country such that no meaningful economic development would take place in any economy without relative peace in the society. This means that the cost of peace is highly valued such that one cannot actually quantify it. It is considered supreme because the worst peace is better than the best war. It is therefore the intention of this paper to x-ray the importance of peace which must be prevalent if any economy will make any headway.

\section{Definition of peace}

Peace is a word that is always uttered by many people on daily basis just like people frequently use the word love, truth or beauty. Yet when one is asked to define peace, it becomes very difficult. The simple definition of peace is that of the Oxford advanced Learners Dictionary which said that "Peace is a state of freedom from war". Albert Einsten argued that "Peace is not only the absence of war but presence of justice, of Law, of Order - in short of Government". Readom (1988) tried to improve on the definition when he added that peace is the absence of violence in its entire ramification which included physical, social, psychological and structural forms. But both definitions seem to be an escape mechanism which does not capture the true contents of peace and peace ingredients. This is because, defining peace merely as absence of war, or dissension or violence is so passive, simplistic, un-detailed and unaccountable to a lot of issues which occurred during the time of conflict. Such fast definition is unresponsive and unanswerable to the residual feelings of those who lost or even won the conflict. Such residual or mutual agony included the feelings of those who lost their parents or children or loved ones. These loses cannot be regained and to erase them from the minds of the looser is very difficult.

Peace therefore should be defined in such a way that all the ingredients of peace such as justice, harmony, tranquility, quiescence, truce, amity, freedom of movement of association, of expression and of worship shall be captured. This is because there may be no war or violence in an environment, yet there is no peace. It is therefore plausible to say that peace is absence of war and presence of freedom, harmony, happiness, and other ingredients of peace. Peace without freedom and happiness is like soup without salt and spices. What this definition suggests is that we prepare peace just as one prepares good soup. The search for lasting peace with the ingredients of peace was described by O Kean (1991) as positive peace which is "a pattern of cooperation and interaction between major human groups... it is about social organization who willingly chose to cooperate for the benefit of all mankind. Woleman (1985. P8) opines that such positive peace is a search for the positive condition which can resolve the underlying causes of conflict that produce violence". In fact, peace should address a positive condition that is devoid of hostility and rancor which is the major characteristics of negative peace. In the words of David Francis, (2006 p 27) "Peace in Africa is not only the absence of war, conflict, fear, distraction and human suffering, but also absence of unequal and unjust structures and cultural practices, about security, democratic participation, respect for human right, development, social progress and justice".

III. Peace And Environment

The fact that peace refers to absence of hostility makes it imperative for peace to depict an environment that is characterized by healthy inter personal and international relationship. An environment that does not 
guarantee safety of life and properties will not attract interest on investment. Such an environment is characterized by low level of social life with its associated low availability of social amenities. A visit to cities like Enugu, Onitsha, Lagos Kano, Kaduna and Jos will discover that cost of social life varies as one move from one zone to the other. The determining factor for such disparity in cost is low level of security of lives and properties in such area.

In Onitsha city for instance, the cost of purchasing a plot of land of same size at the GRA and housing estate Fegge is greatly different from cost of such property at Okpoko axis. This is because there is great sense of security at GRA and Housing Estate Fegge than in Okpoko. Invariably, that sense of security affected all spheres of life in both areas. House rent, stores rent and cost of food stuff soar up in such areas of high security tendency. The effect of this is that it becomes necessary for any investor on properties to be desirous of purchasing land and building at the GRA and Housing estate zone so as to attract high cost of rent. On the other hand, as a result of low cost of rent and cost of food items and other social services, the Okpoko area now has a cluster of low cost houses. This brings about high density population in the area as one can easily find a family of eight people living in a room. The setting makes it difficult for proper training and up bringing as the streets are also filled with many people of different characters. Some of these characters are those who do not find it easy staying in a room with many people. They therefore find it proper to stay outside the house and relax. Some resorted to going to one relaxing joint or the other from where they meet bad friends or the other.

\section{Peace And Entrepreneurship}

The target of any entrepreneur is to make a profit at the end of business transaction. No doubt entrepreneurs are vital in creating of new enterprises that amplifies and energizes the economy. But whereby his target of making a profit is not foreseen, his interest is automatically discouraged. In the words of Stella Mba, (2008: 78) " Every business enterprise seeks to achieve the objectives of survival and growth ... in order to achieve its objectives effectively, a business enterprise must at all times appropriate interaction with its environment". These interactions with the environment plays more important role on the factors of location and culture on business establishment. Any country that has a culture of conflict occurrence and reoccurrence will not be able to attract investment. In this sense peace therefore is a basic requirement to our existence and building attractive culture which will attract investors. The case of Maidugiri Township in Northern Nigeria is an example. The town was known for its major trade on fish stocks, and other live stocks like cattle, sheep and goat. In April 2011, the peaceful nature of the city changed with the constant menace of the dissident Islamic militant group known as Bokoharam who claim to repudiate Western education. The activities of the group resulted in bombing of several strategic locations like churches, markets, hotels and schools. The dastard activities of this group continued unabated even with the presence of military personnel sent to the area by the Federal Government of Nigeria.

The ugly effect of these activities of the Bokoharam sect is that it polluted the business environment and planted fear and sense of insecurity on the residence of Maidugiri. In the midst of insecurity, traders began to relocate to a safer place. Oral interview with Mr. Peter Okeke who was a victim revealed that about $80 \%$ of the Igbo population who formed the bulk of the business population either abandoned their business premises or relocated completely with their entire goods and families. Those who abandoned their stores closed it on the hope that things shall return to normalcy. Another interview with Clement Iheanacho vowed never to travel to Maidugiri for any reason. In his words, "the city which was well known for hospitality was turned to dead zone, within few months... In fact the city may not regain its glory in this generation".

In Jos, the September, $11^{\text {th }} 2001$ riot and other inter-communal conflicts coupled with the recent activities of Bokoharam sect have also polluted business and social activities in the city. The 2001 riot was responsible for the setting ablaze of the Jos ultra modern market. This according to Shedrack (2007:77) was the greatest economic impact of the Jos crises. The market which was one of the best in West Africa has not been reconstructed till date. The implication of these crises is that interest in social and business activities drastically reduced. As Ezeogidi (2009:163) noted " sense of insecurity affected all facets of life, which included commerce and religious activities ... time allocated to business activities was reduced by over fifty percent. Shop owners that used to open their business at $7.00 \mathrm{am}$ and closed at $8.00 \mathrm{pm}$ now changed their habit. They open at 9.00 am and close at $5.00 \mathrm{pm}$.

In October, 1991, Kano city which had a peaceful co-existence was engulfed in bloody conflict that was characterized by wanton killing of lives and destruction of properties. In the words of Rotgak (2004:101) "the city of Kano has an historic past. Existing for more than a thousand years, to the days when it was a famed center in the great age of trans-Saharan savannah trade renowned for its leather and metal crafts". This fame was made possible because of relative peace that existed in the city.

After the October 1991 conflict, the peaceful atmosphere automatically disappeared giving room to the ember of negative peace with its characteristics mutual mistrust, suspicion and lack of beneficial out come. 
In February 2000, Kaduna state recorded crises that almost touched the whole of the country and which reshaped the nature of co-existence thereafter. The effect of these crises was so much. Rotgat (2004: 119) noted that police sources revealed that about 1,944 houses and business centers were destroyed, 609 deaths were recorded, 746 vehicles burnt 123 churches and 55 mosques were burnt, police out post was burnt and over 100 persons sustained injuries of different types. All these could not have happed if peace was not tampered with in different cities of Nigeria.

\section{Peace and The Academic Environment.}

The University and in fact tertiary institutions have four main distinct groups that made up the human components of the institution. These included the students, the non academic staff, the academic staff and the management. Each of these groups is vital in the running of the institution and neglect to any of the groups means impediments to academic progress. Peace in the academic circle therefore must be found in each of the groups. Any dispute between one group and the other will surely affect the other groups.

There are evidences that conflicts have at one time or the other occurred between the management and the academic staff and sometime between students and school authority. Such conflicts sometimes come in the form of disagreement over the school fees increment in the case of student and management. It can come in the form of disagreement over payment of salary arrears or even demand for salary increment or even change in the condition of service in a conflict between the academic staff and the management. Uju Ughamadu (2009) cited some of such conflicts to include the 1978 University of Lagos students' demonstration against increase in feeding fees, the 1989 students' demonstration against the Federal Government introduction of structural adjustment programme. Other examples of such disputes included the 2010 South Eastern States, academic staff union of Universities (ASUU) strike over non compliance of the South Eastern States' Governors to implement ASUU/Federal Government of Nigeria agreement of 2009.

\section{Peace Promotion For Nation Building}

To promote peace for the progress and development of a nation, that nation will involve active participation of all stake holders. These stake holders included the families, the Education institutions, the Government and its ministries as well as the various organs in the country.

In the case of the families, there is no doubt that family is the first institution of socialization. This means that the upbringing of anybody lies on the role of the family. A child begins to learn his right or left from the family. Family in this work simply means the social unit of people who are brought together by marriage ties, blood relationship and child adoption. Obviously, African culture especially before the period of European colonization believed in two main types of families, namely; the nuclear and extended families. The detail of this cultural acceptance is not the concern of this work. The emphasis of this is on the role of the family whether nuclear or extended in the promotion of peace for nation building.

In Igbo family structure, the father is the apex of headship followed by mother, male child and then the female child irrespective of order of seniority. Sometimes the male child are given more regards than the mother, as the mother is not authorized by custom to present kola nut to a visitor or break it in the presence of his son. This over placement of emphasis on male child brings about wrong impression on the male children who now see themselves as superior to women. As such they do not give respect to the female children. These do not augur well for peace which demands reciprocity in respect. Stella Okunna (2004) noted that "when parents support the boy child in his arrogant posture against his sister, he grows to be a husband who is trained to be an oppressor of women". She equally noted that although culture demands that children should respect their parents while parents are under no obligations to accord their children any respect, "there is the need to point out that respect should be mutual or reciprocal even between parents and children for conflict prevention and management". This is a valid statement because evidence abounds that conflicts have erupted simply because a group of people who believe in the inferiority of women claimed that a female erred against their belief. One of the immediate causes of the 2001 conflict in Jos was that a lady passed in front of Muslim worshipers in a mosque along Dilimi street in Jos. Another incidence was a conflict between a male truck pusher and a woman in upper Iweka axis at Onitsha in June 2010. The case was that a truck pusher packed his truck (barrow) by the road side and was sitting in the barrow when a woman drove her car to his location. For lack of parking space, she asked the truck pusher to remove his barrow so that she can park well. The truck pusher obeyed her but when he discovered that it was a woman that parked the car, he angrily went to the woman and slapped her. His argument was that a woman has no right to command a man. When the passerby tried to intervene, (this writer inclusive) the woman begged that the truck pusher should be pardoned because her husband can behave the same way. The most painful aspect of the episode was that the truck pusher had no remorse when it was obvious that the woman was by mere looking older than the truck pusher. The truth is that the behavior of the truck pusher simply depicted the way he was brought up. That also represented the way 
many people were trained for the society. It is therefore very imperative for parents to appreciate the truth that they are training their children for the society. This is because charity as it is said begins at home.

Another way to promote peace is by good leadership or good governance. A good leader must at all times try to be transformational. This can be achieved if a leadership represents interpersonal influence of his followers. The only way a leader can command respect and draw the supports of his followers is when the followers see in the leadership such qualities that are loveable and peaceful. According to Naaba (2006); the followers can only contribute positively when the followers are convinced that they are "following somebody that is worth following not because he threatens them or bullies them but because they believe in him and what he does".

Peace will surely erode a country whose leadership is not conscious of the pains and aspirations of his subordinates. This means that the people will be characterized by agony and hatred which is the agent of conflict. A leader must ensure a perfect structure in which all the departments under him are working well. This will give room for peace and economic development to take place. The emphasis in this paper is that good governance can promote peace if the government has a listening ear and serious with its required responsibility.

Another way to promote peace for nation building is to ensure and guarantee education of the greater population of the country. By education, we mean both formal and informal types of education. Such education must include great emphasis on the importance of peace. There is no doubt that education is not granteed in Nigeria owing to so many factors. One of the factors is the high school fees especially in private and state schools. After the 2010 strike by South Eastern States branches of Academic Staff Union of Universities, against the South Eastern States government for non implementation of ASUU-Federal Government agreement of 2009, all the state universities in the South Eastern zone of Nigeria increasing their school fees. This affected the regular and part-time programme such that a great percentage of the students dropped and their academic carriers chartered. Some of the drop-outs are today roaming around the streets and could easily be lured into bad "boys" group. Therefore it is necessary that more emphasis and supports should be given to education to guarantee the training of the children.

In conclusion, it is the firm believes of this writer that Government at all levels should appreciate the imperativeness of peace for nation building and of course consider peace as a syaquanon to economic growth. By such consideration they will set in motion all necessary structures that will grantee peace in the country. This will include reexamining themselves to see if they represent transformational leadership that carries their subordinates along by showing them what directions to march through and assisting and guiding them when it is necessary. By so doing, the leaders shall be loved and respected by the people and peace will be guaranteed. This will bring about economic development.

\section{References}

[1] Best Shedrack Gaya Indtroduction to peace and conflict studies in west Africa. Ibadan: Spectrum book 2006.

[2] Inegbenor (ed) Fundamentals of Entreprenuership,Lagos Malthouse Press 2006.

[3] David Francis J. "Peace and conflict studies : An African over view of basic concept" in Best Shedrack Gaya in Intruduction to peace and conflict studies in West Africa. Ibadan : Spectrum books 2006.

[4] Ezeogidi, Cyril N.O. and Obikeze O.S.A. (ed) The basic issues in peace and conflict studies in waest Africa. Onitsha : Creative forum, 2009.

[5] Gofwan Rotgak i, Religious conflicts in Northern Nigeria and nation building. Nigeria : Human right monitors, 2004

[6] Okean Quoted in www.Hawaii.edu/pwerkills

[7] Ughamadu Uju. Fundamental issues in peace and conflict situation in Nigeria, Nigeria : Creative forum 2009.

[8] Woolman D.C. "Education and peace in the thoughts of Johan Galtung current : issues in Education and human development education and peace spring 1985 . Vol. 3 .

[9] Oral interview with Mr Peter Okeke, 48years, at Uli on August $6^{\text {th }} 2012$.

[10] Oral interview with Mr Clement Iheanacho 45years,at Nnewi on September 2012 